\title{
Fatty acids in microalgae and cyanobacteria in a changing world: Contrasting temperate and cold environments
}

\author{
Marcelo P. HeRNANDO ${ }^{1,2}$; Irene R. SCHLOSS ${ }^{3,4,5, *}$; Florencia de la ROSA ${ }^{6,7}$; Marleen De TROCH ${ }^{8}$ \\ 1 Comisión Nacional de Energía Atómica (CNEA), Centro Atómico Constituyentes, Departamento de Radiobiología, San Martín, Buenos Aires, Argentina \\ 2 Red de Investigación de Estresores Marinos-costeros en América Latina y el Caribe (REMARCO), Mar del Plata, 7602, Argentina \\ 3 Instituto Antártico Argentino (IAA), San Martín, Buenos Aires, Argentina \\ ${ }^{4}$ Centro Austral de Investigaciones Científicas (CADIC-CONICET), Ushuaia, 9410, Argentina \\ 5 Universidad Nacional de Tierra del Fuego, Ushuaia, 9410, Argentina \\ ${ }^{6}$ Instituto de Ciencias Básicas y Experimentales (ICBE), Universidad de Morón, Morón, Buenos Aires, Argentina \\ 7 Consejo Nacional de Investigaciones Científicas y Técnicas (CONICET), Buenos Aires, Argentina \\ ${ }^{8}$ Ghent University, Faculty of Sciences, Biology Department, Marine Biology, Ghent, 9000, Belgium
}

Key words: Antarctic, Temperate, Essential FAs, Increased temperature, Microalgae, Cyanobacteria

\begin{abstract}
Under the present changing climate conditions and the observed temperature increase, it is of high importance to understand its effects on aquatic microbial life, and organisms' adaptations at the biochemical level. To adjust to temperature or salinity stress and avoid cell damage, organisms alter their degree of fatty acids (FAs) saturation. Thus, temperature is expected to have strong effects on both the quantity and quality of FAs in aquatic microorganisms. Here we review some recent findings about FAs sensitivity to climate change in contrasting environments. Overall, heat waves may induce changes in the relative abundance of polyunsaturated FAs (PUFA). However, the impact of the exposure to warming waters is different in temperate and polar environments. In cold marine waters, high concentration of omega-3 ( $\omega 3$ ) FAs such as eicosapentaenoic acid (EPA) is promoted due to the activation of the desaturase enzyme. In this way, cells have enough energy to produce or activate antioxidant protection mechanisms and avoid oxidative stress due to heat waves. Contrastingly, under high irradiance and heat wave conditions in temperate environments, photosystems' protection is achieved by decreasing EPA concentration due to desaturase sensitivity. Essential FAs are transferred in aquatic food webs. Therefore, any alteration in the production of essential FAs by phytoplankton (the main source of $\omega 3$ ) due to climate warming can be transferred to higher trophic levels, with cascading effects for the entire aquatic ecosystem.
\end{abstract}

\section{Introduction}

Increasing fossil fuel emissions during the past decades have increased atmospheric $\mathrm{CO}_{2}$ concentrations and lead to a rise of global average temperatures (Myhre et al., 2015; Abhilash, 2015). The average surface temperature of the planet increased around $1{ }^{\circ} \mathrm{C}$ during 2019 , being the second warmest year in the 140-year record (NOAA, 2020). Temperature is expected to further increase globally with larger changes at higher latitudes (Perkins-Kirkpatrick and Gibson, 2017). Predictions made by the Intergovernmental Panel on Climate Change (IPCC, 2019) indicate that the surface temperature would increase approximately from 3 to

^Address correspondence to: Irene R. Schloss, ireschloss@gmail.com Received: 30 April 2021; Accepted: 10 August 2021 $5^{\circ} \mathrm{C}$ by 2100 . Furthermore, the average ocean temperature increased by $0.06^{\circ} \mathrm{C}$ per decade in the last 50 years (Lindsey and Dahlman, 2017). As a result of the increased surface and air temperatures and the frequency of extreme heat days, the marine and freshwater temperatures will also continue to rise (IPCC, 2019).

Aquatic ecosystems such as large shallow lakes are particularly vulnerable to climate change (van Doorslaer et al., 2007). For example, it could produce substantial coastline changes (Pussella et al., 2015). However, the increases in temperature vary regionally.

The physico-chemical properties of polar environments are shifting rapidly, especially in the Arctic and in areas around the Antarctic Peninsula. In the Arctic Ocean, a $2^{\circ} \mathrm{C}$ increase was observed over the last 20 years (Economist, 2013). Temperature records for the West Antarctic Peninsula 
(WAP) have shown the largest average atmospheric warming in the Southern Hemisphere, accompanied by significant warming of surface and deeper waters, salinity changes and rapid glaciers retreat (Henley et al., 2019). Moreover, marine ecosystems will be affected depending on the duration and intensity of the heat wave (Frölicher and Laufkötter, 2018) and the capacity of marine biota to adapt their physiology to the exposure to altered conditions (Doney et al., 2012).

In the marine realm, a number of environmental factors determine the productivity of phytoplankton assemblages, many of which are affected by global climate change, ozone depletion and pollution (Winder and Sommer, 2012; Häder and Gao, 2015; Häder et al., 2015). Temperature is a crucial factor, which controls growth and productivity through phytoplankton photosynthesis (Thyssen et al., 2011; Raymont, 2014; Hernando et al., 2015). In this manner, productivity shows a positive correlation with the increase in temperature up to species optimum (Huertas et al., 2011). Changes in species composition are already being observed in response to altered temperature patterns (Larsson et al., 2015; Hernando et al., 2015, 2020; Antoni et al., 2020), considering that the ability to adapt to such changes are species-specific in a phytoplankton assemblage (Gao et al., 2012). Consequently, the pronounced variability in oceanatmosphere exchanges of heat along WAP has a strong impact on primary production, community composition and ecosystem functioning (Ducklow et al., 2013; Meredith et al., 2017; Hernando et al., 2015).

In freshwater systems, high inputs of nutrients usually favor phytoplankton growth and photosynthesis (Falkowski et al., 1998; Behrenfeld et al., 2006), which promoted an increase in the frequency of cyanobacterial blooms in the last decades. Additionally, warmer temperatures and eutrophication are often proposed as principal factors favoring these events (Chorus and Bartram, 1999; Paerl and Huisman, 2008). These blooms are further associated with a decrease in phytoplankton diversity (Oliver and Gand, 2000). Other environmental factors promoting the predominance of cyanobacteria are irradiance conditions (with optimum values between spring and autumn), the ability to fix atmospheric nitrogen, high $\mathrm{pH}$ (6.5 to 8.5), low rate of filtration by zooplankton and the ability to form gas vesicles (Martin, 2000; Paerl and Huisman, 2008).

Cyanobacteria are an excellent source of peptides, FAs, amino acids, vitamins, minerals and pigments (Mimouni et al., 2012). On the other hand, diatoms are the most abundant phytoplankton species and major primary producers in the oceans and are recognized as the most ecologically successful microalgae (Obata et al., 2013). Diatom's membranes are usually enriched with medium-chain FAs as well as very long chain polyunsaturated fatty acids (PUFA) (Zulu et al., 2018). These unsaturated FAs (UFAs) play vital roles in membrane physiology. In addition, the ratio of UFAs to saturated FAs (SFA) determines membrane fluidity, which promotes several cellular activities (Altabe et al., 2013). The optimal membrane fluidity to sustain physiological homeostasis is achieved by upward or downward regulation of UFAs synthesis ('homeoviscous adaptation', Hazel, 1995). Temperature stress may induce changes in the FAs of cell membranes to avoid damage and be protected against the effects of increased temperature (de la Rosa et al., 2020). This adaptation allows cyanobacteria and microalgae such as diatoms to survive in extreme conditions and involves remodeling membrane lipids by modifying FAs chain length and unsaturation to sustain the desired level of fluidity in cell membranes (Sinensky, 1974).

Changes in PUFA in response to environmental stressors are highly relevant for the ecological role of cyanobacteria and microalgae as food sources for grazers and can therefore have serious implications for the flow of energy and the overall functioning of the ecosystem (Twining et al., 2021).

The study of the changes induced by elevated seawater temperature in FAs and lipid metabolism enzymes of diatoms can provide insight into the impacts of marine heat waves on these organisms and on the potential repercussions on the entire marine food webs and ecosystems (Galloway and Winder, 2015). Changes in FAs metabolism and alterations in the expression of key genes (An et al., 2013; Shimojima et al., 2009) could be a response to environmental stresses such as heat waves.

Overall, organisms' responses to heat waves may involve reversible adjustment of their physiology by changing the content of some biomolecules or with activation of antioxidant systems, among other processes (Hernando et al., 2015; Hernando et al., 2018; Hernando et al., 2020; de la Rosa et al., 2020). Because phytoplankton growth and composition are highly dependent on environmental conditions (Galloway and Winder, 2015; Antoni et al., 2020), there is an urgent need to understand how microalgae will be affected at the biochemical level in our warming world. Also, algae inhabiting regions at different latitudes are adapted to different ranges of temperatures.

The aim of this review is to compare the microalgae and cyanobacteria response from cold $v s$. temperate and tropical waters, to heat waves in relation to climate change and summarize the mechanisms of action leading to the observed FAs changes.

\section{Importance of Fatty Acids and Their Role in Ecosystems}

There are two major groups of FAs: SFA and UFAs, which differentiate from each other by the existence of double bonds in UFAs. The position of the double bonds is determined by the desaturase enzyme activity, which performs its activity in different positions accordingly to the type of enzyme present in different organisms (Brett and Müller-Navarra, 1997). SFA are mainly considered a source of energy and lipid storage. UFAs can be identified by the number of double bonds: Monounsaturated FAs (MUFAs) have one double bond and can be synthesized de novo almost by all organisms (Arts et al., 2001). PUFA are FAs of 18 carbons or more in length with two or more double bonds. They can be classified into $n-6$ (or $\omega 6$ ) and $n-3$ (or $\omega 3)$ major groups, depending on the position of the first double bond proximate to the methyl end of the FAs.

FAs synthesis in algae occurs through an aerobic pathway (Monroig et al., 2013), it takes place in the chloroplast and the endoplasmic reticulum (ER). The glucose produced by photosynthesis is converted by glycolysis to pyruvate, which is the molecular basis for all metabolism processes. The desaturation and elongation process takes place in the ER. It uses $18: 1 \omega 9$ to form linoleic 


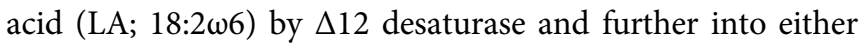
the $\omega 6$ pathway by $\Delta 6$ desaturase or into the $\omega 3$ pathway by $\Delta 15$ desaturase to form alpha-linolenic acid (ALA; 18:3w3). Different organisms utilize a diverse amount of desaturases to come to the different PUFA as shown in Fig. 1.

In consumers, PUFA play an essential role in brain development (Liu et al., 2015) and many physiological functions such as down regulating inflammation and cellular signaling (Stillwell and Wassall, 2003). Essential FAs are some PUFA that play major important functions in physiological and biochemical processes. These must be acquired through dietary input, considering that the majority of the animals cannot synthesize them de novo (Kattner and Hagen, 2009) due to the lack of the desaturase enzyme (Sargent et al., 1993).

Phytoplankton accounts for nearly 50\% of net primary production on Earth, and is the source of many biomolecules (Field et al., 1998) such as FAs (Guschina and Harwood, 2009) which are crucial components of the biosphere (Beardall et al., 2009). PUFA play an important role in the food web because they affect key physiological processes and are precursors to many hormones (Jónasdóttir et al., 2009; de Troch et al., 2012). Thus, PUFA are critical regulators of the survival, reproduction, and

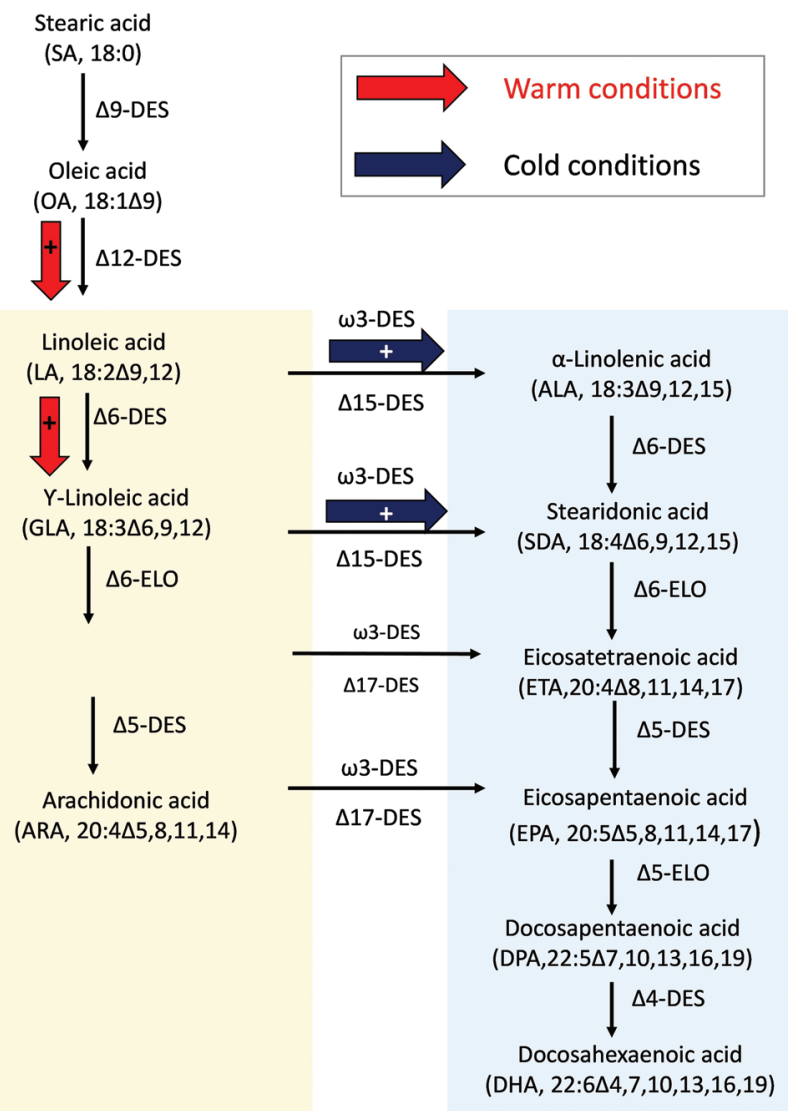

\section{Omega-6 Pathway}

Omega-3 Pathway

FIGURE 1. Simplified desaturation pathway of the FAs synthesis in phytoplankton cells. Des: Desaturase, Elo: elongase. Modified from Jónasdóttir et al. (2009) and Vaezi et al. (2013). The arrows indicate potential changes in the $\omega 6$ and $\omega 3$ FAs production path as a function of temperature. Red and black arrows indicate high or low temperature conditions, respectively. population growth in invertebrates and fish (Copeman et al., 2002; Von Elert, 2004).

Long-chain $\omega 3$ FAs, particularly eicosapentaenoic acid

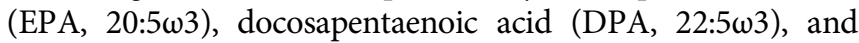
docosahexaenoic acid (DHA, 22:6w3) have been specially studied due to their important physiological functions and because the human body is unable to synthesize these compounds de novo (Drouin et al., 2019). The brain has a high content of DHA, representing $50 \%$ of the total brain lipid and 10-15\% of all of the FAs (Diau et al., 2005). EPA was also found to be present at low concentrations in the brain (Chen et al., 2009) probably because it rapidly converts to DHA (Kaur et al., 2010). EPA in the brain provides important anti-inflammatory and immunity functions, but also plays an important role in neurotransmission and synaptic plasticity (Tassoni et al., 2008; Uauy et al., 2000).

In general terms, lipids produced by phytoplankton provide energy and essential nutrients for consumers in aquatic (Guschina and Harwood, 2009; Parrish, 2013) and terrestrial ecosystems (Gladyshev et al., 2009; Hixson et al., 2015). The herbivorous zooplankton and the fish that prey on them cannot synthesize all the FAs or cannot synthesize them in amounts required for optimal physiological performance (Brett et al., 2006; Arts et al., 2009). Hence, consumers acquire the required essential FAs from dietary lipids supplied by phytoplankton FAs, for example, LA,

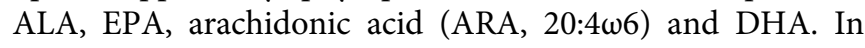
addition to their nutritive role, lipids form the backbone of the lipid bilayer in cell membranes (Arts et al., 2009; Parrish, 2013). Although microalgae are the primary producers of EPA and DHA in marine food webs, humans use marine fish oil as the principal source of these PUFA (Sinclair, 2000). Moreover, the marine fish industry is increasingly declining due to overfishing and environmental pollution, while the production costs of DHA or EPA from cultured algae are potentially equal to the cost of producing EPA from fish oil (Milledge, 2011) and lower than the costs of PUFA from shellfish flesh and by-products (Al Khawli et al., 2019; Dvoretsky et al., 2021). Different algal taxa exhibit different FAs profiles (Harwood, 1998; Napolitano, 1999) as shown in Table 1 and Fig. 2). Jónasdóttir (2019) revealed a phyla-specific, and a highly species-specific PUFA production of marine phytoplankton, showing that the highest proportion of PUFA is found in Chlorophyta and Cryptophyta, and the lowest in Ochrophyta, Cyanobacteria and diatoms (Maltse and Maltseva, 2021). Diatoms are an important nutrition source in the marine environment, since many species produce large quantities of EPA (Arao et al., 1987; Dunstan et al., 1994). Both EPA and DHA are particularly found in diatoms, dinoflagellates and prymnesiophytes (Tonon et al., 2002; Mansour et al., 2005), they are produced from their precursor, ALA which is considered an essential FAs (Cook and McMaster, 2004).

Some $\omega 3$ are mainly synthesized by producers in aquatic environments (Hixson et al., 2015; Twining et al., 2015). These PUFA are progressively consumed and selectively retained by other aquatic organisms higher up in the food chain (Kainz et al., 2004; Hixson et al., 2015), and transferred to terrestrial ecosystems via consumption (Gladyshev et al., 2009, 2013). Thus, PUFA composition of 


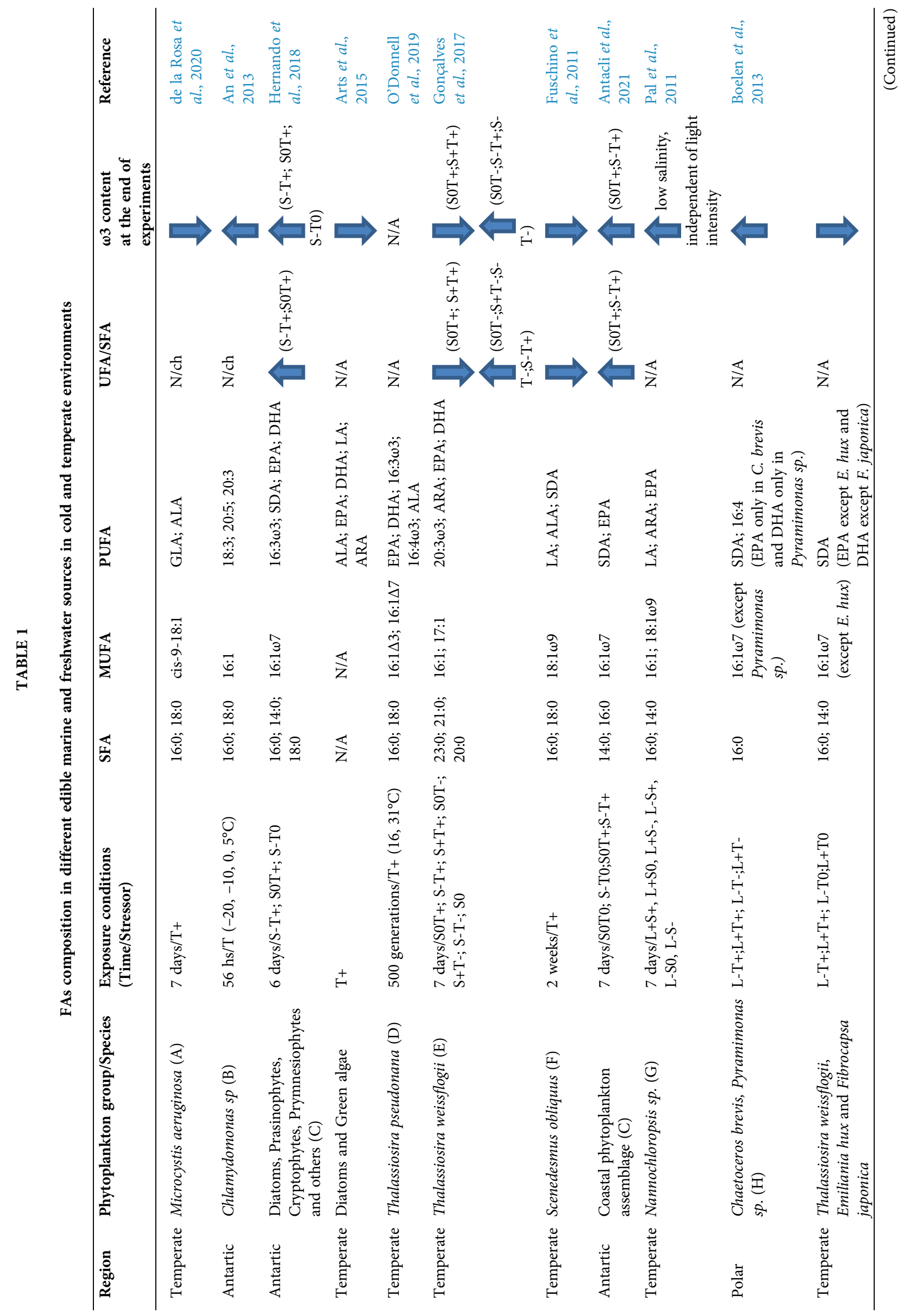




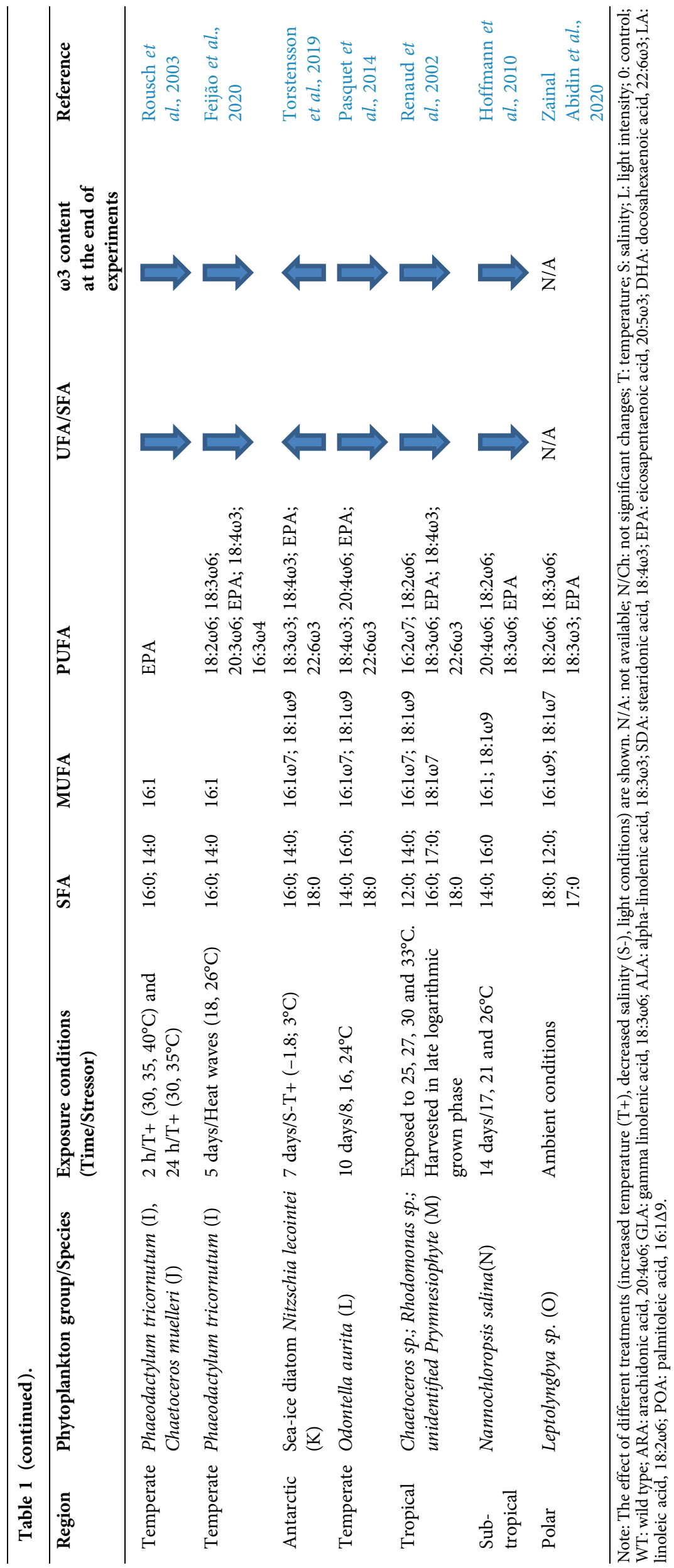




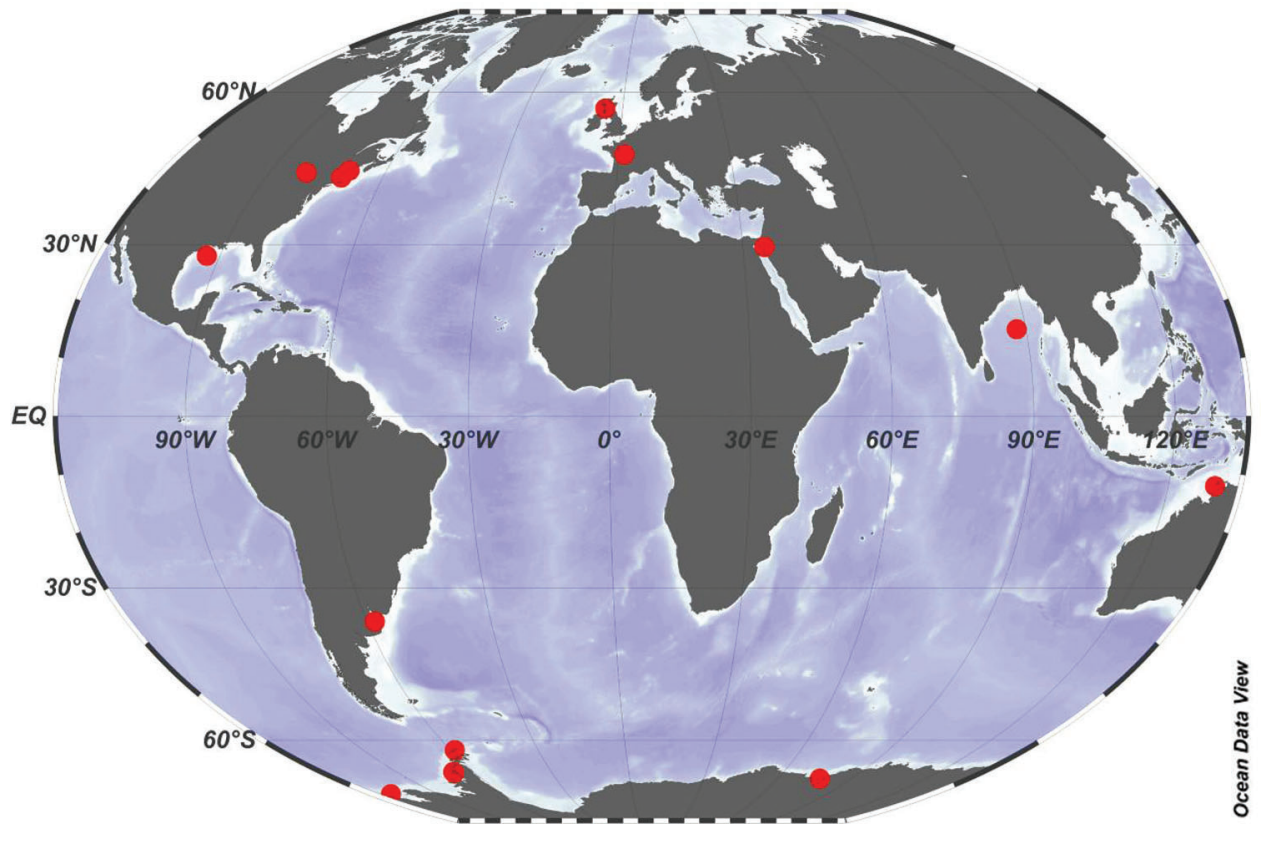

FIGURE 2. Distribution of studies on the effects of temperature increase on microalgae and cyanobacteria FAs composition. Red dots denote positioning and letters from the Roman alphabet correspond to the phytoplankton species or groups indicated in Table 1. phytoplankton is an important determinant of food quality and, consequently, the health and optimal functioning of both aquatic and terrestrial consumers (Budge et al., 2002; Dalsgaard et al., 2003).

\section{Changes in Membrane Fatty Acids}

Temperature has strong directional effects on both the quantity and quality of FAs in phytoplankton. Phytoplankton and other organisms adapt to changing temperatures by modifying the structure of their membranes (Winter and Dzwolak, 2005), a process known as homeoviscous adaptation (see above). The double bonds in PUFA increase flexibility, leading to increased membrane fluidity. Under a sudden change in environmental conditions, de novo synthesis of UFAs cannot occur rapidly, but the desaturation of FAs may be adjusted by transferring specific acyl groups to other polar lipids and allowing rapid adaptive membrane reorganization (KhozinGoldberg and Cohen, 2006). Temperature changes may then induce the replacement of an enzyme by an isoenzyme with better heat- or cold-tolerance (Steele and Fry, 2000). Several authors have shown an inverse relationship between temperature and FAs unsaturation in microalgae (Wada et al., 1990; Zhu et al., 1997).

PUFA represent between 30 and $60 \%$ of total FAs content in natural polar ocean assemblages and in individual phytoplankton species (Teoh et al., 2004). Hernando et al. (2018) described the predominance of PUFA (44-64\% in average) over SFA for Antarctic coastal phytoplankton at the beginning of microcosm experiments to evaluate the effects of increased temperature and decreased salinity on physiology (Table 1, Fig. 2).

In polar region, cyanobacteria mats from streams and lakes are dominated by Nostoc or oscillatorians (Oscillatoriaceae) (Zainal Abidin et al., 2020) with extreme accumulations up to $90 \mathrm{~cm}$ thick and > $40 \mu \mathrm{g}$ Chla $\mathrm{cm}^{-2}$ at some sites. Picocyanobacteria often dominate the phytoplankton in polar lakes achieving some of the highest natural concentrations on record, up to $8 \times 10^{6}$ cells $\mathrm{mL}^{-1}$ in some Antarctic lakes
(Vincent, 2000). In marine waters in the Southern Ocean, picocyanobacteria were found to decrease during spring (Massana et al., 1998) and summer (Murray et al., 1998), and it has been speculated that the significant decline of archaea during spring/summer is a result of the competition with nonarchaeal microorganisms during phytoplankton blooms (Massana et al., 1998). Regarding FA studies in these organisms, Zainal Abidin et al. (2020) demonstrated a high content of UFAs in four of the five isolated species of the filamentous cyanobacterium Leptolyngbya sp. from fine Antarctic mats. The $\omega 6$ linoleic acid reached an average percentage of $60 \%$ followed by palmitoleic acid (10\%) and oleic acid (10\%) as shown in Table 1 and Fig. 2.

Contrarily to observations in Antarctic waters, Ohse et al. (2015) found in a FAs study with temperate marine species (Nannochloropsis oculata, Thalassiosira pseudonana, Phaeodactylum tricornutum, Isochrysis galbana, Tetraselmis suecica, Tetraselmis chuii, Chaetoceros muelleri, Thalassiosira fluviatilis and Isochrysis sp.) and the freshwater Chlorella sp, that average PUFA in these species was around 20\%. Also, the cyanobacteria Microcystis aeruginosa, showed a PUFA relative abundance around $40 \%$ of the total FAs (de la Rosa et al., 2020).

Water temperature is one of the most important factors in the regulation of PUFA synthesis by microalgae or cyanobacteria and their accumulation by zooplankton. Thus, global warming may lead to a decrease of PUFA in aquatic ecosystem (Thompson et al., 1992; Renaud et al., 2002; Maazouzi et al., 2008) in order to maintain fluidity (see above). Conversely, acclimation to increasing temperature involves decreasing PUFA membrane content, while, simultaneously, increasing SFA (Rousch et al., 2003; Fuschino et al., 2011) as shown in Table 1.

\section{Consequences of the Increase in Temperature in the Composition of FAS in Temperate and Tropical vs. Cold Environments}

An important consequence of climate change is that increasing water temperatures are expected to reduce the 
global production of PUFA in phytoplankton. The environment temperature and salinity affect the FA profile of microalgae, and it was found that DHA content decreases significantly with an increase in water temperature and salinity (Adarme-Vega et al., 2012). Similarly, the EPA content was also found to decrease considerably with an increase in water temperature (Sang et al., 2012). Changes in the biochemical composition of phytoplankton cell membranes may lead to cascading effects throughout the world's aquatic ecosystems. Further, such modified biochemical composition in aquatic ecosystems, as mentioned above, is also anticipated to propagate to terrestrial animals because of the flux of aquatic biomass, containing $\omega 3$ PUFA (Gladyshev et al., 2009; Gladyshev et al., 2013). This is critical because PUFA not only enhance the growth rates and reproductive capacities of aquatic animals (Ballantyne et al., 2003), but are also vitally important to the neural/cognitive, cardiovascular, and visual health of terrestrial vertebrates (Calder, 2015).

\section{Antarctic Waters}

Rapid changes in temperature and salinity may have great effects on the physiology and biochemical composition of Antarctic diatoms. Hernando et al. (2018) and Antacli et al. (2021) demonstrated that EPA increased in Antarctic coastal phytoplankton assemblage in response to stress (increased temperature combined with freshening), in concordance with results from Teoh et al. (2013) as shown in Table 1 and Fig. 2. An et al. (2013) working with the Antarctic ice algae Chlamydomonas sp. and considering the FA desaturase (FADs) expression, demonstrated an increased amount of EPA in cells exposed to 0 and $5^{\circ} \mathrm{C}$ in comparison to controls at $-10^{\circ} \mathrm{C}$. This is related to the strategies adopted for survival at low temperatures, which include an increasing degree of FAs unsaturation or branching and a decrease in the FAs chain length (Penfield, 2008). An et al. (2013) results indicated that the mRNAs of FADs in Chlamydomonas sp. were regulated differentially in response to temperature stress. Moreover, those desaturases involved in $\omega 3$ production as shown in Fig. 1 were found to be sensitive to low temperature, indicating that they might play primary roles in protecting algal cells from potential damage at low temperature. Furthermore, when cells of the Antarctic sea-ice diatom Nitzschia lecointei were grown at $3^{\circ} \mathrm{C}$, they had higher relative PUFA content (mainly

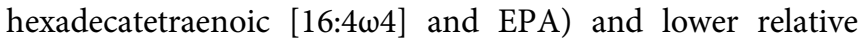
MUFAs content than cells grown at $-1.8^{\circ} \mathrm{C}$ (Torstensson et al., 2019). Diatoms isolated from sea ice show a FAs composition characterized by high levels of EPA and C16 PUFA (Henderson et al., 1998). Analysis of the FAs of a natural Arctic phytoplankton assemblage showed that, when dominated by diatoms of the genera Thalassiosira and Chaetoceros, the proportions of C16:1( $\omega 7)$ and EPA were correspondingly high (Reuss and Poulsen, 2002).

Most algae produce EPA via the $\omega 3$ pathway as shown in Fig. 1. The biosynthesis of EPA occurs through a series of reactions that can be divided into two distinct steps. First is the de novo synthesis of oleic acid (OA, 18:1w9) from acetate. $\mathrm{OA}$ is further desaturated by a $\Delta 12$ desaturase to form LA and a $\Delta 15$ desaturase to form ALA. Then, $\omega 6$ and $\omega 3$ FAs families are formed from their precursors by a series of desaturation and elongation reactions, including EPA as shown in Fig. 1. The three FAs, OA, LA and ALA, compete with each other for the D6 desaturase. The affinity of the enzyme to the substrate and the amount of substrate available determine which metabolic pathway is predominant (Gurr, 1985). Generally, the first $\Delta 6$ desaturation is the limiting step and ALA has the highest affinity for $\Delta 6$ desaturase followed by LA and oleic acid (Jónasdóttir, 2019). In order to enhance EPA production in Dunaliella salina (a green alga), FAs desaturares $(\Delta 6)$ FADS6 from the diatom Thalassiosira pseudonana, Shi et al. (2018) constructed and overexpressed in D. salina with a plasmid (Ds-TpFADS6). They demonstrated that EPA production increased significantly in D. salina transformants. However, after Ds-TpFADS6 transformants were maintained at low temperature $\left(4^{\circ} \mathrm{C}\right)$ for 5 days, their ALA levels increased but LA levels decreased. From this, they concluded that the activity of other desaturase enzymes overexpressed in D. salina, Ds-FADS15 $(\Delta 15)$, was enhanced at low temperature, promoting the conversion of LA to ALA and increasing the ALA level as show in Fig. 1. These findings are similar to those of Okuda et al. (2015), who observed an accumulation of EPA in Mortierella alpina at low temperature (below $15^{\circ} \mathrm{C}$ ). Ds-FADS15 and Ds-FADS6 in $M$. alpine transformants had high activity and exhibited greater EPA accumulation under varying temperatures than under constant temperatures, suggesting a more active LA-ALA-EPA pathway under these conditions. There was also less LA flux through the $\omega 6$ pathway as shown in Fig. 1.

EPA or other long-chain PUFA (LC-PUFA) may play a role in the functioning of the thylakoid membrane and are therefore essential for photosynthesis (Cohen et al., 1988). At higher irradiance, photosynthesis is less efficient and thus fewer thylakoid membranes are required. As a result, LCPUFA content could be lower in high light-acclimated algae (Harwood and Jones, 1989). Hence, cold-adapted polar microalgae could have high EPA and DHA production, since they can exhibit high growth rates under low temperature and irradiance conditions. Furthermore, polar species are expected to sustain a higher EPA and DHA content, since their habitat is characterized by lower average irradiance and temperature levels (Schloss et al., 2002).

Changes in salinity may also modify the composition of FA and influence the physiological properties of microalgae (Hernando et al., 2018). Due to the increase in the occurrence of heat waves in the WAP, melt water and seawater freshening increased. Xu and Beardall (1997) demonstrated that the content of $\omega 3$ in Dunaliella sp. decreased as the average salinity increased. In a culture of the marine diatom Nitzschia laevis, EPA yield was the highest at half the salinity of the artificial seawater (Wen

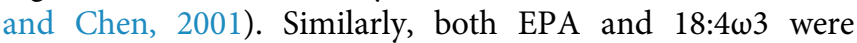
significantly higher in natural Antarctic phytoplankton assemblages after $48 \mathrm{~h}$ exposure at salinities 4 PSU lower than environmental values (Hernando et al., 2018).

High level of intracellular molecular oxygen may be another reason for the increased PUFA at low temperature, because the enzymes responsible for desaturation and elongation of PUFA depend on the availability of molecular 
oxygen (Chen and Johns, 1991; Singh and Ward, 1997). A temperature shift strategy has been employed to enhance the overall $\omega 3$ PUFA production (including EPA) because the optimal temperature for microalgal growth is often higher than that for $\omega 3$ PUFA formation (Jiang and Chen, 2000). Such a phenomenon has been observed in many different algal species including Porphyridium cruentum (Springer et al., 1994), Nannochloropsis sp. (Sukenik, 1991) and P. irregulare (Stinson et al., 1991).

To the best of our knowledge, there are no studies testing the effects of temperature increase on FA of Antarctic cyanobacteria. In a recent latitudinal study, Breton et al. (2020) demonstrated that the distribution of marine Synechococcus cyanobacteria depends on the differentiation of lineages adapted to distinct thermal environments. Over the temperature gradient they sampled, all strains maintained efficient photosynthetic capacities. Subpolar and cold temperature strains actually showed enhanced capacities for lipid monodesaturation thanks to an additional $\Delta 9$-desaturase. By contrast, tropical and warm temperature strains displayed moderate monodesaturation capacities but high proportions of double unsaturations in response to cold temperatures, thanks to $\Delta 12$-desaturases. The desaturase genes displayed specific distributions directly related to latitudinal variations in ocean surface temperature. Thus, this study highlights the critical importance of membrane fluidity modulation by desaturases in the adaptive strategies.

\section{Temperate and Tropical Waters}

Many studies have shown changes in the FAs composition of microalgae and cyanobacteria from temperate waters when exposed to changes in temperature. Phaeodactylum tricornutum has been used as a model organism for diatom physiology studies, being the first pennate diatom to have its genome completely sequenced (Bowler et al., 2008). It has been shown that this species has the ability to produce up to $35 \%$ of EPA of total FA (Hamilton et al., 2014). The thylakoid membrane of $P$. tricornutum is composed of uncharged glycolipids such as monogalactosyldiacylglycerol (MGDG) and digalactosyldiacylglycerol (DGDG) (Yang et al., 2017), with EPA being the most abundant component of the glycolipids (Mühlroth et al., 2013). Jiang and Gao (2004) explained that elevated levels of UFAs in the diatom $P$. tricornutum after $12 \mathrm{~h}$ of exposure to low temperatures were due to increased activity of desaturase. Other studies have shown similar changes in the FA composition in diatoms within a similar period of time $(12-48 \mathrm{~h}$ ) (Tonon et al., 2002; Siron et al., 1989; Liang et al., 2006). Thompson et al. (1992) who studied the effect of temperature over the range from 10 to $25^{\circ} \mathrm{C}$ on the FA composition of eight species of marine phytoplankton, including Thalassiosira pseudonana and three species within the genus Chaetoceros also showed a trend towards elevated PUFA at a lower temperature. However, only for T. pseudonana the percentage of DHA decreased linearly with increasing temperature. Blanchemain and Grizeau (1999) noted that the diatom Skeletonema costatum increased its EPA levels relative to dry weight at only the lowest $\left(15^{\circ} \mathrm{C}\right)$ of three treatment temperatures and that there was a positive correlation between treatment duration (4 or $15 \mathrm{~h}$ ) and EPA production at a particular temperature.

Species of the genus Nannochloropsis (Eustigmatophyceae, Monodopsidaceae) from sub-tropical sea waters are an important source of the essential EPA and are widely used in marine aquaculture nutrition (Renaud and Parry, 1994). The quality of Nannochloropsis biomass for aquaculture (high EPA percentage of total FAs) has been shown to deteriorate with culture age and with increasing light intensity, salinity level, and temperature. In addition, a concomitant increase in the proportions of saturated and monounsaturated fatty acids 14:0, 16:0, and 16:1 was found (Sukenik et al., 1993; Renaud and Parry, 1994; Roncarati et al., 2004). Hoffmann et al. (2010) also described this trend for Nannochloropsis salina with increased EPA contents under a low culture temperature $\left(17^{\circ} \mathrm{C}\right)$ as compared to moderate temperatures of $21^{\circ} \mathrm{C}$ and $26^{\circ} \mathrm{C}$ (Table 1, Fig. 2).

Renaud et al. (2002) also demonstrated a decrease in the total production of the PUFA, including significant decreases

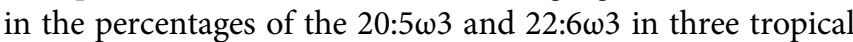
Australian species of Rhodomonas sp., an unidentified prymnesiophyte and a Chaetoceros sp. at higher growth temperatures between $33^{\circ} \mathrm{C}$ and $35^{\circ} \mathrm{C}$ when harvested during in late logarithmic growth phase. These results concurs with the findings of previous studies (Mortensen et al., 1988; Renaud et al., 1995) as shown in Table 1 and Fig. 2.

For the temperate Chlamydomonas, temperature stress (variation from optimum) caused an increase in SFA (Teoh et al., 2013). The increase in SFA could be an important energy source for stress adaptation in these microalgae. The role of UFAs in membrane fluidity has been demonstrated in other algae such as Spirulina platensis (Sushchik et al., 2003), Chlamydomonas sp. (Poerschmann et al., 2004), and C. vulgaris strain BI (Morgan-Kiss et al., 2008) when subjected to temperature stress. Pal et al. (2011) demonstrated that the eustigmatophyte Nannochloropsis sp. accumulate energy-rich storage products when exposed to unfavorable conditions that limit growth as long as the carbon supply exceeds the photosynthetic capacity of the cells. Also, low temperatures resulted in higher lipid production in Nitzschia palea (Renaud et al., 1995), Chaetoceros sp. (Clone CS256) (Renaud et al., 2002) and Chaetoceros cf. wighamii (de Castro Araujo and Garcia, 2005).

Qiao et al. (2016) found a higher DHA/EPA ratio in $P$. tricornutum grown under altered environmental conditions. DHA percentage increased with increasing light intensity, but decreased with increasing temperature. Furthermore, Feijão et al. (2017) also working with P. tricornutum from temperate ocean waters, demonstrated that cells exposed to heat wave conditions showed lower relative EPA contents and double bond indexes, whereas the $\omega 6 / \omega 3$ ratio increased like in the cyanobacteria Microcystis aeruginosa (de la Rosa et al., 2020). Moreover, the analysis of the FAs profiles in $P$. tricornutum also suggested that heat exposure negatively impacted thylakoid lipids, in agreement with the decrease observed in photosynthesis. Oxygen-evolving complexes are essential for the water splitting reaction occurring at the donor side of the photosystem II (PSII) and essential not only for oxygen production but also for fueling the quinone pool with the necessary energy for electron transport from 
PSII to PSI (Strasser et al., 2000). These complexes are usually heat-sensitive (Duarte et al., 2016) and therefore heat waves may have a negative impact on photosynthesis and cells' nutritional value, as well as on their capacity to oxygenate ocean water.

In order to get further insights on the influence of gene expression in the changes of lipid classes and FAs composition on $P$. tricornutum as a consequence of heat waves, Feijão et al. (2020) analysed key genes responsible for the biosynthesis of some lipids, FAs desaturation of plastidial $\Delta 6$ desaturase and extraplastidial $\Delta 5$ desaturase lipids, as well as phospholipases. The results obtained indicate that storage lipids decrease in response to a heat wave. Besides changing the proportion of membrane/storage lipids, the heat wave also affected the FAs composition of all lipid classes. As a general trend, there is a decrease in PUFA and an increase in saturated or, in some cases, monounsaturated FAs. This could be a mechanism to stabilize the membrane (Feijão et al., 2020). Moreover, Feijão showed that after exposure to heat, the gene encoding the plastidial $\Delta 6$ FAs desaturase showed a significant increase. Thus, although no significant change occurred in the $\Delta 5$ desaturase transcripts amounts, lower amounts of EPA were detected. Under extreme temperature stress (up to $30^{\circ} \mathrm{C}$ ) $P$. tricornutum hardly shows any growth (Jiang and Gao, 2004) and effects on lipid metabolism are drastic (e.g. no EPA content) (Dodson et al., 2014). This mechanism could involve gene expression regulation of genes related to membrane lipids synthesis e.g. MGDG (with high EPA content). Under non-lethal growth temperatures, $P$. tricornutum could prioritize thylakoid membrane stability and therefore photosynthesis over membrane quality (Feijão et al., 2020).

The marine picocyanobacterium Synechococcus is one of the most conspicuous and widely distributed species in the world, with high importance for net primary productivity (Flombaum et al., 2013). Studies of the FAs desaturaserelated genes in Synechococcus have determined the presence of four main distinct genes, encoding two $\Delta 9$ - (desC3 and desC4) and two $\Delta 12$-desaturases (desA2 and desA3; Varkey et al., 2016). Synechococcus has a different physiological strategies based on the presence of specific lipid desaturase gene sets, allowing them to cope with changes in the fluidity of the photosynthetic membrane in different thermal conditions. In a recent latitudinal study, Breton et al. (2020) have shown the distribution of such lipid desaturase genes at 33 widespread stations along the Tara Oceans transect. The desaturase gene desC4, which is specific for cold-adapted strains, was found exclusively in waters colder than $20^{\circ} \mathrm{C}$, consistent with its hypothesized role of a monodesaturation enhancer enabling growth in cold thermal environments. In warm environments, there is little need to have FAs variations in membrane, and marine Synechococcus have adopted a different strategy. They constitutively contain membrane $\Delta 12$ lipids with more double unsaturation thanks to DesA2, a desaturase specific to warm environments $\left(30-32^{\circ} \mathrm{C}\right) . \Delta 9$ desaturases were selected in colder environments during the evolution of marine Synechococcus as shown in Fig. 1. Thus, after shifting the culture temperature down from 38 to $22^{\circ} \mathrm{C}$, Sakamoto et al. (1997) demonstrated for Synechococcus sp. PCC 7002 strain that the degree of unsaturation of C18 FAs increased in cells grown at low temperature. The desaturation at the $\omega 3$ position of $\mathrm{C} 18$ increased gradually during a 12-h period in cells grown at $22^{\circ} \mathrm{C}$. Various desaturases in cyanobacteria and higher plants are known to be affected by temperature at the level of gene transcription (Los et al., 1997). Wada and Murata (1990) demonstrated that FAs desaturases enzymes play an important role in cold acclimation of cyanobacteria. The microalgal genome contains genes coding for the synthesis of molecules involved in survival mechanisms and FA synthesis ( $\mathrm{Li}$ et al., 2014). In these organisms, de la Rosa et al. (2020) demonstrated a differential sensitivity of $\omega 3$ and $\omega 6$ FA to high temperature. They observed decreased relative concentration of $18: 4 \omega 3$ and $18: 3 \omega 3$ at $29^{\circ} \mathrm{C}$ after 10 days exposure as compared to exposure to $26^{\circ} \mathrm{C}$. Previous studies also have shown an effect of temperature on the FA composition, and specifically a decrease in $\omega 3$ PUFA (EPA and DHA) with increasing temperature. Thus, Sushchik et al. (2003) demonstrated a decrease of $\omega 3$ FA desaturase due to increased temperature in Chlorella vulgaris and Botryococcus braunii resulted in a decrease in the relative content of the more unsaturated intracellular FAs, especially the trienoic FAs like ALA. Also, for Thalassiosira pseudonana, the percentage of 22:6w3 decreased linearly with increasing temperature over the range from 10 to $25^{\circ} \mathrm{C}$ (Thompson et al., 1992).

Hence, the adaptation of $M$. aeruginosa to temperature rise could be related to a decrease and an increase in the activity of $\omega 3$ and $\omega 6$-desaturases, respectively. The high relative abundance of cis-18:1 $\omega 9$, observed in high temperature conditions from day 1 of incubation and until the end of the 10-days experiment (de la Rosa et al., 2020), could explain the significant increase of the PUFA $\omega 6$, considering that this MUFAs cis-18:1 $\omega 9$ is a precursor of the $\omega 6$ FAs (Akoh and Min, 2008).

\section{Conclusions}

FAs in phytoplankton and cyanobacteria display structural changes and high biological specificity, responding to stress conditions. Their biosynthesis is inhibited or enhanced depending on the temperature the organisms are exposed to, along with alterations in the processes of FAs desaturation and elongations. Hence, FAs are useful bioindicators of the ecological and health status of aquatic ecosystems. They provide crucial information about the impact of global stressors on aquatic communities and thus on the food web, with severe repercussions to human beings among other terrestrial animals, and food quality. Moreover, lipids and proteins are involved in the most vital functions of aquatic organisms. Thus, the reduction of essential FAs content at the base of the food web may have serious implications for higher trophic levels.

As consequences of climate change effects on marine and freshwater ecosystems, intensive agriculture production with the usage of fertilizers and pesticides near coastal wetlands will have severe impacts on the aquatic communities and thus to whole the ecosystem. Therefore, it is of major importance and becomes a priority to determine and predict the effects of environmental and anthropogenic stressors on the aquatic systems in order to promote their health and preserve biodiversity and food quality. 
Overall, heat wave-induced changes in the relative abundance of PUFA, and more importantly EPA, are alarming because of their importance in aquatic ecosystems. However, the impact of the exposure of aquatic communities to climate change variables is different between temperate/tropical and polar environments. In cold marine waters the activation of desaturase is promoted towards high-energy $\omega 3$ FAs such as EPA. Conversely, in temperate and tropical environments, the decrease in EPA as a function of desaturases sensitivity protects the photosystems in conditions of high irradiance and heat waves.

Availability of Data and Materials: Data sharing not applicable to this article as no datasets were generated or analyzed during the current study.

Author Contributions Statement: The authors confirm contribution to the paper as follows: $\mathrm{MH}$ and IS participated in the designing of the original idea and in the manuscript writing. FD and MD contributed to the bibliographic search and in the manuscript writing. All authors have approved the final version of the article.

Funding Statement: The research leading to these results further received funding grants ANPCYT PICT 2011-130 Raíces of the Agencia Nacional de Promociones Científicas of Argentina to IRS and MPH, and from the European Union's Horizon 2020 research and innovation program under grant agreement No. 730984, ASSEMBLEPLUS2019359 Project awarded to FD. It is further a contribution to CoastCarb (Funding ID 872609, H2020, MSCA-RISE-2019, Research and Innovation Staff Exchange).

Conflicts of Interest: The authors declare that they have no conflicts of interest to report regarding the present study.

\section{References}

Abhilash C (2015). Carbon footprint-A review. International Journal of Scientific Research Today 2: 116-126.

Adarme-Vega TC, Lim DK, Timmins M, Vernen F, Li Y, Schenk PM (2012). Microalgal biofactories: A promising approach towards sustainable n-3 fatty acid production. Microbial Cell Factories 11: 96-106.

Akoh CC, Min DB (2008). Food lipids: chemistry, nutrition, and biotechnology. In: Akoh CC, Min DB (eds.), Food Lipids: Chemistry, Nutrition, and Biotechnology, Third edition, pp. 427-432. CRC Press, Taylor and Francis Group, New York.

Al Khawli F, Pateiro M, Domínguez R, Lorenzo JM, Gullón P, Kousoulaki K, Ferrer E, Berrada H, Barba FJ (2019). Innovative green technologies of intensification for valorization of seafood and their by-products. Marine Drugs 17: 689.

Altabe SG, Mansilla MC, de Mendoza D (2013). Remodeling of membrane phospholipids by bacterial desaturases. In: Ntambi J (ed.), Stearoyl-CoA Desaturase Genes in Lipid Metabolism, pp. 209-231. New York: Springer.

An M, Mou S, Zhang X, Ye N, Zheng Z, Cao S, Xu D, Fan X, Wang Y, Miao J (2013). Temperature regulates fatty acid desaturases at a transcriptional level and modulates the fatty acid profile in the Antarctic microalga Chlamydomonas sp. ICE-L. Bioresource Technology 134: 151-157.

Antacli JC, Hernando MP, de Troch M, Malanga G, Mendiolar M, Hernández DR, Varela DE, Antoni J, Sahade RJ, Schloss IR
(2021). Ocean warming and freshening effects on lipid metabolism in coastal Antarctic phytoplankton assemblages dominated by sub-Antarctic species. Science of the Total Environment 790: 147879.

Antoni JS, Almandoz GO, Ferrario ME, Hernando MP, Varela DE, Rozema PD, Buma AGJ, Paparazzo FE, Schloss IR (2020). Response of a natural Antarctic phytoplankton assemblage to changes in temperature and salinity. Journal of Experimental Marine Biology and Ecology 532: 151444.

Arao T, Kawaguchi A, Yamada M (1987). Positional distribution of fatty acids in lipids of the marine diatom Phaeodactylum tricornutum. Phytochemistry 26: 2573-2576.

Arts MT, Ackman RG, Holub BJ (2001). Essential fatty acids in aquatic ecosystems: A crucial link between diet and human health and evolution. Canadian Journal of Fisheries and Aquatic Sciences 58: 122-137.

Arts MT, Brett MT, Kainz MJ (2009). Lipids in Aquatic Ecosystems. New York: Springer, 308.

Arts MT, Hixson SM, Mercieca S (2015). Climate warming reduces essential fatty acid production in algae. Journal of Environmental Indicators 9: 7-8.

Ballantyne AP, Brett MT, Schindler DE (2003). The importance of dietary phosphorus and highly unsaturated FAs for sockeye (Oncorhynchus nerka) growth in Lake Washington-A bioenergetics approach. Canadian Journal of Fisheries and Aquatic Sciences 60: 12-22.

Beardall J, Ihnken S, Quigg A (2009). Gross and net primary production: Closing the gap between concepts and measurements. Aquatic Microbial Ecology 56: 113-122.

Behrenfeld M, O'Malley R, Siegel D, McClain CR, Sarmiento JL, Feldman GC, Milligan AJ, Falkowski PG, Letelier RM, Boss ES (2006). Climate-driven trends in contemporary ocean productivity. Nature 444: 752-755.

Blanchemain A, Grizeau D (1999). Increased production of eicosapentaenoic acid by Skeletonema costatum cells after decantation at low temperature. Biotechnology Techniques 13: 497-501.

Boelen P, van Dijk R, Damsté JSS, Rijpstra WIC, Buma AG (2013). On the potential application of polar and temperate marine microalgae for EPA and DHA production. AMB Express 3: 1-9.

Bowler C, Allen A, Badger J, Grimwood J, Jabbari K et al. (2008). The Phaeodactylum genome reveals the evolutionary history of diatom genomes. Nature 456: 239-244.

Breton S, Jouhet J, Guyet U, Gros V, Pittera J et al. (2020). Unveiling membrane thermoregulation strategies in marine picocyanobacteria. New Phytologist 225: 2396-2410.

Brett MT, Müller-Navarra DC (1997). The role of highly unsaturated fatty acids in aquatic food web processes. Freshwater Biology 38: $483-499$.

Brett MT, Müller-Navarra DC, Ballantyne A, Ravet JL, Goldman CR (2006). Daphnia fatty acid composition reflects that of their diet. Limnology and Oceanography 51: 2428-2437.

Budge SM, Iverson SJ, Bowen D, Ackman RG (2002). Among- and within-species variability in fatty acid signatures of marine fish and invertebrates on the Scotian Shelf, Georges Bank, and southern Gulf of St. Lawrence. Canadian Journal of Fisheries and Aquatic Sciences 59: 886-898.

Calder PC (2015). Functional roles of fatty acids and their effects on human health. Journal of Parenteral and Enteral Nutrition 39: $18 \mathrm{~S}-32 \mathrm{~S}$.

Chen CT, Liu Z, Ouellet M, Calon F, Bazinet RP (2009). Rapid $\beta$ oxidation of eicosapentaenoic acid in mouse brain: An in 
situ study. Prostaglandins, Leukotrienes, and Essential Fatty Acids 80: $157-163$.

Chen F, Johns MR (1991). Effect of C/N ratio and aeration on the fatty acid composition of heterotrophic Chlorella sorokiniana. Journal of Applied Phycology 3: 203-209.

Chorus I, Bartram J (1999). Toxic Cyanobacteria in Water: A Guide to Their Public Health Consequences, Monitoring and Management. London: World Health Organization, E\&FN Spon, Routledge.

Cohen Z, Vonshak A, Richmond A (1988). Effect of environmental conditions on fatty acid composition of the red alga Porphyridium cruentum: Correlation to growth. Journal of Phycology 2: 328-332.

Cook HW, McMaster CR (2004). Fatty acid desaturation and chain elongation in eukaryotes. In: Vance DE, Vance JE (eds.), Biochemistry of Lipids, Lipoproteins and Membranes. New Comprehensive Biochemistry, pp. 181-204. Amsterdam: Elsevier.

Copeman LA, Parrish CC, Harel M, Brown JA (2002). Effects of docosahexaenoic, eicosapentaenoic, and arachidonic acids on the early growth, survival, lipid composition and pigmentation of yellowtail flounder (Limanda ferruginea): A live food enrichment experiment. Aquaculture 210: 285-304.

Dalsgaard J, St. John M, Kattner G, Mueller-Navarra DC, Hagen W (2003). Fatty acid trophic markers in the pelagic marine food environment. Advances in Marine Biology 46: 225-234.

de Castro Araujo S, Garcia VMT (2005). Growth and biochemical composition of the diatom Chaetoceros cf. wighamii brightwell under different temperature, salinity and carbon dioxide levels. I. Protein, carbohydrate and lipids. Aquaculture 246: 405-412.

de la Rosa F, de Troch M, Malanga G, Hernando M (2020). Differential sensitivity of fatty acids and lipid damage in Microcystis aeruginosa (cyanobacteria) exposed to increased temperature. Comparative Biochemistry and Physiology Part C: Toxicology \& Pharmacology 235: 108773.

de Troch M, Boeckx P, Cnudde C, van Gansbeke D, Vanreusel A, Vincx M, Caramujo M (2012) Bioconversion of fatty acids at the basis of marine food webs: Insights from a compound specific stable isotope analysis. Marine Ecology Progress Series 465: 53-67.

Diau GY, Hsieh AT, Sarkadi-Nagy E, Wijendran V, Nathanielsz PW, Brenna JT (2005). The influence of long chain polyunsaturate supplementation on docosahexaenoic acid and arachidonic acid in baboon neonate central nervous system. BMC Medicine 3: 11.

Dodson VJ, Mouget JL, Dahmen JL, Leblond JD (2014). The long and short of it: Temperature-dependent modifications of fatty acid chain length and unsaturation in the galactolipid profiles of the diatoms Haslea ostrearia and Phaeodactylum tricornutum. Hydrobiologia 727: 95-107.

Doney S, Ruckelshaus M, Duffy J, Barry J, Chan F et al. (2012). Climate change impacts on marine ecosystems. Annual Review of Marine Science 4: 11-37.

Drouin G, Rioux V, Legrand P (2019). The n-3 docosapentaenoic acid (DPA): A new player in the n-3 long chain polyunsaturated fatty acid family. Biochimie 159: 36-48.

Duarte AG, Katata G, Hoshika Y, Hossain M, Kreuzwieser J, Arneth A, Ruehr NK (2016). Immediate and potential long-term effects of consecutive heat waves on the photosynthetic performance and water balance in Douglas-fir. Journal of Plant Physiology 205: 57-66. DOI 10.1016/j.jplph.2016.08.012.

Ducklow HW, Fraser WR, Meredith MP, Stammerjohn S, Doney SC et al. (2013). West Antarctic Peninsula: An ice-dependent coastal marine ecosystem in transition. Oceanography 26: 190-203. DOI 10.5670/oceanog.2013.62.

Dunstan GA, Volkman JK, Barrett SM, Leroi JM, Jeffrey SW (1994). Essential polyunsaturated fatty acids from 14 species of diatom (Bacillariophyceae). Phytochemistry 35: 155-161. DOI 10.1016/S0031-9422(00)90525-9.

Dvoretsky AG, Bichkaeva FA, Baranova NF, Dvoretsk VG (2021). Fatty acid composition of the Barents Sea red king crab (Paralithodes camtschaticus) leg meat. Journal of Food Composition and Analysis 98: 103826. DOI 10.1016/j. jfca.2021.103826.

Economist (2013). http://www.economist.com/news/science-andtechnology/21571386.

Falkowski P, Barber R, Smetacek V (1998). Biogeochemical controls and feedbacks on ocean primary productivity. Science 281: 200-206. DOI 10.1126/science.281.5374.200.

Feijão E, Franzitta M, Cabrita MT, Caçador I, Duarte B, Gameiro C, Matos AR (2020). Marine heat waves alter gene expression of key enzymes of membrane and storage lipids metabolism in Phaeodactylum tricornutum. Plant Physiology and Biochemistry 156: $357-368$.

Feijão E, Gameiro C, Franzitta M, Duarte B, Caçador I, Cabrita MT, Matos AR (2017). Heat wave impacts on the model diatom Phaeodactylum tricornutum: Searching for photochemical and fatty acid biomarkers of thermal stress. Ecological Indicators 95: 1026-1037.

Field CB, Behrenfeld MJ, Randerson JT, Falkowski P (1998). Primary production of the biosphere: Integrating terrestrial and oceanic components. Science 281: 237-240.

Flombaum P, Gallegos JL, Gordillo RA, Rincón J, Zabala LL et al. (2013). Present and future global distributions of the marine Cyanobacteria Prochlorococcus and Synechococcus. Proceedings of the National Academy of Sciences, USA, 110: 9824-9829.

Frölicher TL, Laufkötter C (2018). Emerging risks from marine heat waves. Nature Communications 9: 2015-2018.

Fuschino JR, Guschina IA, Dobson G, Yan ND, Harwood JL, Arts MT (2011). Rising water temperatures alter lipid dynamics and reduce n-3 essential FA concentrations in Scenedesmus obliquus. Journal of Phycology 47: 763-774.

Galloway AWE, Winder M (2015). Partitioning the relative importance of phylogeny and environmental conditions on phytoplankton fatty acids. PLoS One 10: e0130053. DOI 10.1371/journal.pone.0130053.

Gao K, Helbling EW, Häder DP, Hutchins DA (2012). Responses of marine primary producers to interactions between ocean acidification, solar radiation, and warming. Marine Ecology Progress Series 470: 167-189. DOI 10.3354/meps10043.

Gladyshev M, Arts MT, Sushchik N (2009). Preliminary estimates of the export of omega-3 highly unsaturated fatty acids (EPA + DHA) from aquatic to terrestrial ecosystems. In: Arts MT, Brett MT, Kainz MJ (eds.), Lipids in Aquatic Ecosystems, pp. 179-210. New York: Springer.

Gladyshev M, Sushchika O, Makhutova N (2013). Production of EPA and DHA in aquatic ecosystems and their transfer to the land. Prostaglandins Other Lipid Mediators 107: 117-126. DOI 10.1016/j.prostaglandins.2013.03.002.

Gonçalves A, Marques JC, Gonçalves F (2017). Fatty acids' profiles of aquatic organisms: Revealing the impacts of environmental and anthropogenic stressors. Fatty Acids 89-118.

Gurr MI (1985) Biosynthesis of fats. In: Padley FB, Podmore J (Eds.), The Role of Fats in Humand Nutrition, pp. 24-28. Ellis Horwood, Ltd., Chichester. 
Guschina IA, Harwood JL (2009). Algal lipids and effect of the environment on their biochemistry. In: Arts MT, Brett MT, Kainz MJ (eds.), Lipids in Aquatic Ecosystems, pp. 1-24. New York: Springer.

Häder DP, Gao K (2015). Interactions of anthropogenic stress factors on marine phytoplankton. Frontiers in Environmental Science 3: 14.

Häder DP, Williamson CE, Wangberg SA, Rautio M, Rose KC, Gao K, Helbling EW, Sinha RP, Worrest RP (2015). Effects of UV radiation on aquatic ecosystems and interactions with other environmental factors. Photochemical \& Photobiological Sciences 14: 108-126. DOI 10.1039/C4PP90035A.

Hamilton M, Haslam R, Napier J, Sayanova O (2014). Metabolic engineering of microalgae for enhanced production of omega-3 long chain polyunsaturated fatty acids. Metabolic Engineering 22: 3-9. DOI 10.1016/j.ymben.2013.12.003.

Harwood JL (1998). Membrane lipids in algae. In: Siegenthaler PA, Murata N (eds.), Lipids in Photosynthesis: Structure, Function and Genetics, pp. 53-63. Dordrecht: Kluwer Academic Publishers.

Harwood JL, Jones AL (1989). Lipid-metabolism in algae. Advances in Botanical Research 16: 1-53. DOI 10.1016/S0065-2296 (08)60238-4.

Hazel JR (1995). Thermal adaptation in biological membranes: Is homeoviscous adaptation the explanation? Annual Review of Physiology 57: 19-42. DOI 10.1146/annurev.ph.57.030195.000315.

Henderson RJ, Hegseth EN, Park MT (1998). Seasonal variation in lipid and fatty acid composition of ice algae from the Barents Sea. Polar Biology 20: 48-55. DOI 10.1007/s003000050275.

Henley SF, Schofield OM, Hendry KR, Schloss IR, Steinberg DK et al. (2019). Variability and change in the west Antarctic Peninsula marine system: Research priorities and opportunities. Progress in Oceanography 173: 208-237. DOI 10.1016/j.pocean.2019.03.003.

Hernando M, Schloss IR, Almandoz GO, Malanga G, Varela DE, de Troch M (2018). Combined effects of temperature and salinity on fatty acid content and lipid damage in Antarctic phytoplankton. Journal of Experimental Marine Biology and Ecology 503: 120-128. DOI 10.1016/j.jembe.2018.03.004.

Hernando M, Schloss IR, Malanga G, Almandoz GO, Ferreyra GA, Aguiar MB, Puntarulo S (2015). Effects of salinity changes on coastal Antarctic phytoplankton physiology and assemblage composition. Journal Experimental Marine Biology Ecology 466: 110-119. DOI 10.1016/j.jembe.2015.02.012.

Hernando M, Varela DE, Malanga G, Almandoz GO, Schloss IR (2020). Effects of climate-induced changes in temperature and salinity on phytoplankton physiology and stress responses in coastal Antarctica. Journal of Experimental Marine Biology and Ecology 530: 151400.

Hixson SM, Sharma B, Kainz MJ, Wacker A, Arts MT (2015). Production, distribution, and abundance of long-chain omega3 polyunsaturated fatty acids: A fundamental dichotomy between freshwater and terrestrial ecosystems. Environmental Reviews 23: 414-424. DOI 10.1139/er-2015-0029.

Hoffmann M, Marxen K, Schulz R, Vanselow KH (2010). TFA and EPA productivities of Nannochloropsis salina influenced by temperature and nitrate stimuli in turbidostatic controlled experiments. Marine drugs 8: 2526-2545

Huertas IE, Rouco M, Lopez-Rodas V, Costas E (2011). Warming will affect phytoplankton differently: Evidence through a mechanistic approach. Proceedings of the Royal Society B: Biological Sciences 278: 3534-3543. DOI 10.1098/ rspb.2011.0160.
IPCC (2019). IPCC special report on the ocean and cryosphere in a changing climate. In: Pörtner HO, Roberts DC, MassonDelmotte V, Zhai P, Tignor M et al. Geneva: IPCC.

Jiang H, Gao K (2004). Effects of lowering temperature during culture on the production of polyunsaturated fatty acids in the marine diatom Phaeodactylum tricuornutum (Bacillariophyceae). Journal of Phycology 40: 651-654.

Jiang Y, Chen F (2000). Effects of temperature and temperature shift on docosahexaenoic acid production by the marine microalga Crypth ecodinium cohnii. Journal of the American Oil Chemists' Society 77: 613-617.

Jónasdóttir S (2019). Fatty acid profiles and production in marine phytoplankton. Marine Drugs 17: 151.

Jónasdóttir SH, Visser AW, Jespersen C (2009). Assessing the role of food quality in the production and hatching of Temora longicornis eggs. Marine Ecology Progress Series 382: 139-150.

Kainz MJ, Arts MT, Mazumber A (2004). Essential fatty acids in the planktonic food web and their ecological role for higher trophic levels. Limnology and Oceanography 49: 1784-1793.

Kattner G, Hagen W (2009). Lipids in marine copepods: latitudinal characteristics and perspective to global warming. In: Lipids in Aquatic Ecosystems, pp. 257-280. Springer, New York, NY.

Kaur G, Begg DP, Barr D, Garg M, Cameron-Smith D, Sinclair AJ (2010). Short-term docosapentaenoic acid (22: $5 \mathrm{n}$-3) supplementation increases tissue docosapentaenoic acid, DHA and EPA concentrations in rats. British Journal of Nutrition 103: 32-37.

Khozin-Goldberg I, Cohen Z (2006). The effect of phosphate starvation on the lipid and fatty acid composition of the fresh water eustigmatophyte Monodus subterraneus. Phytochemistry 67: 696-701.

Larsson U, Nyberg S, Zakrisson A, Hajdu S (2015). Baltic Sea phytoplankton: Long-term variability of major groups and primary production in spring and summer related to nutrients and temperature. http://su.diva-portal.org/smash/ record.jsf?pid=diva2\%3A783358\&dswid=-4719.

Li J, Han D, Wang D, Ning K, Jia J et al. (2014). Choreography of transcriptomes and lipidomes of Nannochloropsis reveals the mechanisms of oil synthesis in microalgae. Plant Cell 26: $1645-1665$

Liang Y, Beardall J, Heraud P (2006). Changes in growth, chlorophyll fluorescence and fatty acid composition with culture age in batch cultures of Phaeodactylum tricornutum and Chaetoceros muelleri (Bacillariophyceae). Botanica Marina 49: 165-173.

Lindsey R, Dahlman L (2017). Climate change: Global temperature. https://www.climate.gov/news-features/understanding-climate/ climate-change-globaltemperature.

Liu JJ, Green P, Mann JJ, Rapoport SI, Sublette ME (2015). Pathways of polyunsaturated fatty acid utilization: Implications for brain function in neuropsychiatric health and disease. Brain Research 1597: 220-246.

Los DA, Ray MK, Murata N (1997). Differences in the control of the temperature-dependent expression of four genes for desaturases in Synechocystis sp. PCC 6803. Molecular Microbiology 25: 1167-1175.

Maazouzi C, Masson G, Izquierdo MS, Pihan GC (2008). Midsummer heat wave effects on Lacus_trine Plankton: Variation of assemblage structure and fatty acid composition. Journal of Thermal Biology 33: 287-296.

Maltse Y, Maltseva K (2021). Fatty acids of microalgae: Diversity and applications. Reviews in Environmental Science and Bio/ Technology 20: 515-547. 
Mansour MP, Frampton DMF, Nichols PD, Volkman JK, Blackburn SI (2005). Lipid and fatty acid yield of nine stationary-phase microalgae: Applications and unusual C-24-C-28 polyunsaturated fatty acids. Journal of Applied Phycology 17: $287-300$.

Martin T (2000). Cianobacterial dominance in lakes. Hydrobiology 438: 1-12. DOI 10.1023/A:1004155810302.

Massana R, Taylor LT, Murray AE, Wu KY, Jeffrey WH, Delong EF (1998). Vertical distribution and temporal variation of marine planktonic archaea in the during early spring. Limnology Oceanography 43: 607-617. DOI 10.4319/lo.1998.43.4.0607.

Meredith MP, Stammerjohn SE, Venables HJ, Ducklow HW, Martinson DG et al. (2017). Changing distributions of sea ice melt and meteoric water west of the Antarctic Peninsula. Deep Sea Research Part II: Topical Studies in Oceanography 139: 40-57. DOI 10.1016/j.dsr2.2016.04.019.

Milledge JJ (2011). Commercial application of microalgae other than as biofuels: A brief review. Reviews in Environmental Science and Biotechnology 10: 31-41. DOI 10.1007/s11157010-9214-7.

Mimouni V, Ulmann L, Pasquet V, Mathieu M, Picot L, Bougaran G, Cadoret JP, Morant-Manceau A, Schoefs B (2012). The potential of microalgae for the production of bioactive molecules of pharmaceutical interest. Current Pharmaceutical Biotechnology 13: 2733-2750. DOI 10.2174/138920112804724828.

Monroig Ó, Tocher DR, Navarro JC (2013). Biosynthesis of polyunsaturated fatty acids in marine invertebrates: Recent advances in molecular mechanisms. Marine Drugs 11: 3998-4018.

Morgan-Kiss RM, Ivanov AG, Modla S, Czymmek K, Hüner NPA, Priscu JC, Lisle JT, Hanson TE (2008). Identity and physiology of a new psychrophilic eukaryotic green alga, Chlorella sp., strain BI, isolated from a transitory pond near Bratina Island. Antarctica Extremophiles 12: 701-711.

Mortensen SH, Borsheim KY, Rainuzzo JK, Knutsen G (1988). Fatty acid and elemental composition of the marine diatom Chaetoceros gracilis Schutt. Effects of silicate deprivation, temperature and light intensity. Journal Experimental Marine Biology and Ecology 122: 173-185.

Mühlroth A, Li K, Røkke G, Winge P, Olsen Y, Hohmann-Marriott MF, Vadstein O, Bones AM (2013). Pathways of lipid metabolism in marine algae, co-expression network, bottlenecks and candidate genes for enhanced production of EPA and DHA in species of Chromista. Marine Drugs 11: 4662-4697.

Murray AE, Preston CM, Massana R, Taylor LT, Blakis A, Wu K, DeLong EF (1998). Seasonal and spatial variability of bacterial and archaeal assemblages in the coastal waters near Anvers Island. Antarctica Applied and Environmental Microbiology 64: 2585-2595.

Myhre G, Boucher O, Breon FM, Forster P, Shindell D (2015). Declining uncertainty in transient climate response as $\mathrm{CO}_{2}$ forcing dominates future climate change. Nature Geoscience 8: 181-185.

Napolitano GE (1999). Fatty acids as trophic and chemical markers in freshwater ecosystems. In: Arts MT, Wainman BC (eds.), Lipids in Freshwater Ecosystems, pp. 21-44. New York: Springer.

NOAA (2020). National Centers for Environmental Information, State of the Climate: Global Climate Report for Annual 2019. https://www.ncdc.noaa.gov/sotc/global/201913.

Obata T, Fernie A, Nunes-Nesi A (2013). The central carbon and energy metabolism of marine diatoms. Metabolites 3: 325-346.
O’Donnell DR, Du ZY, Litchman E (2019). Experimental evolution of phytoplankton fatty acid thermal reaction norms. Evolutionary applications 12: 1201-1211.

Ohse S, Derner RB, Ozório RÁ, Corrêa RG, Furlong EB, Cunha PCR (2015). Lipid content and fatty acid profiles in ten species of microalgae. Idesia 33: 93-101.

Okuda T, Ando A, Negoro H, Muratsubaki T, Kikukawa H, Sakamoto T, Sakuradani E, Shimizu S, Ogawa J (2015). Eicosapentaenoic acid (EPA) production by an oleaginous fungus Mortierella alpina expressing heterologous the $\Delta 17$ desaturase gene under ordinary temperature. European Journal of Lipid Science and Technology 117: 1919-1927.

Oliver RL, Gand GG (2000). Freshwater blooms. In: Whiton BA, Potts M (eds.), The Ecology of Cyanobacteria, pp. 149-194. Dordrecth: Kluwer Academic Press.

Paerl HW, Huisman J (2008). Blooms like it hot. Science 320: 57-58.

Pal D, Khozin-Goldberg I, Cohen Z, Boussiba S (2011). The effect of light, salinity, and nitrogen availability on lipid production by Nannochloropsis sp. Applied Microbiology Biotechnology 90: 1429-1441.

Parrish C (2013). Lipids in marine ecosystems. ISRN Oceanography 2013: 1-16. DOI 10.5402/2013/604045.

Pasquet V, Ulmann L, Mimouni Guihéneuf F, Jacquette B, Manceau A, Gérard T (2014). Fatty acids profile and temperature in the cultured marine diatom Odontella aurita. Journal of Applied Phycology 26: 2265-2271.

Penfield S (2008). Temperature perception and signal transduction in plants. New Phytolist 179: 615-628.

Perkins-Kirkpatrick SE, Gibson PB (2017). Changes in regional heatwave characteristics as a function of increasing global temperature. Scientific Reports 7: 12256.

Poerschmann J, Spijkerman E, Langer U (2004). Fatty acid patterns in Chlamydomonas sp. as a marker for nutritional regimes and temperature under extremely acidic conditions. Microbial Ecology 48: 78-89.

Pussella PGRNI, Gunathilake J, Bandara KRMU, Dammalage T, Jayakody J (2015). Coastline changes: Vulnerability and predictions-A case study of the northwestern coastal belt of Sri Lanka. Tourism, Leisure and Global Change 2: 125-154.

Qiao H, Cong C, Sun C, Li B, Wang J, Zhang L (2016). Effect of culture conditions on growth, fatty acid composition and DHA/EPA ratio of Phaeodactylum tricornutum. Aquaculture 452: 311-317.

Raymont JE (2014). Plankton \& Productivity in the Oceans: Volume 1: Phytoplankton. Elsevier, Pergamon Press, Oxford, England.

Renaud SM, Parry DL (1994). Microalgae for use in tropical aquaculture II: Effect of salinity on growth, gross chemical composition and fatty acid composition of three species of marine microalgae. Journal of Applied Phycology 6: 347-356.

Renaud SM, Thinh LV, Lambrinidis G, Parry DL (2002). Effect of temperature on growth, chemical composition and fatty acid composition of tropical Australian microalgae grown in batch cultures. Aquaculture 211: 195-214.

Renaud SM, Zhou HC, Parry DL, Thinh LV, Woo KC (1995). Effect of temperature on the growth, total lipid content and fatty acid composition of recently isolated tropical microalgae Isochrysis sp., Nitzschia closterium, Nitzschia paleacea, and commercial species Isochrysis sp. (clone T.ISO). Journal of Applied Phycology 7: 595-602.

Reuss N, Poulsen LK (2002). Evaluation of fatty acids as biomarkers for a natural plankton community. A field study of a spring bloom and a post-bloom period off West Greenland. Marine Biology 141: 423-434. 
Roncarati A, Meluzzi A, Acciarri S, Tallarico N, Meloti P (2004). Fatty acid composition of different microalgae strains (Nannochloropsis sp., Nannochloropsis oculata (Droop) Hibberd, Nannochloris atomus Butcher and Isochrysis sp.) according to the culture phase and the carbon dioxide concentration. Journal of the World Aquaculture Society 35: 401-411.

Rousch JM, Bingham SE, Sommerfeld MR (2003). Change in fatty acid profiles of thermos-intolerant and thermo-tolerant marine diatoms during temperature stress. Journal of Experimental Marine Biology and Ecology 295: 145-156.

Sakamoto T, Higashi S, Wada H, Murata N, Bryant DA (1997). Lowtemperature-induced desaturation of fatty acids and expression of desaturase genes in the cyanobacterium Synechococcus sp. PCC 7002. FEMS Microbiology Letters 152: 313-320.

Sang M, Wang M, Liu J, Zhang C, Li A (2012). Effects of temperature, salinity, light intensity, and $\mathrm{pH}$ on the eicosapentaenoic acid production of Pinguiococcus pyrenoidosus. Journal of Ocean University of China 11: 181-186.

Sargent JR, Bell JG, Bell MV, Henderson RJ, Tocher DR (1993). The metabolism of phospholipids and polyunsaturated fatty acids in fish. In: Lahlou B, Vitiello P (eds.), Aquaculture: Fundamental and Applied Research Coastal and Estuarine Studies, pp. 103112. Washington DC: American Geophysical Union.

Schloss IR, Ferreyra GA, Ruiz-Pino D (2002). Phytoplankton biomass in antarctic shelf zones: A conceptual model based on Potter Cove, King George Island. Journal of Marine Systems 36: 129-143.

Shi H, Luo X, Wu R, Yue X (2018). Production of eicosapentaenoic acid by application of a delta- 6 desaturase with the highest ALA catalytic activity in algae. Microbial Cell Factories 17: 7.

Shimojima M, Tsuchiya M, Ohta H (2009). Temperature-dependent hyper-activation of monoglucosyldiacylglycerol synthase is post-translationally regulated in Synechocystis sp. PCC 6803. FEBS Letters 583: 2372-2376.

Sinclair R (2000). Good, bad or essential fats: What is the story with Omega-3? Nutrition \& Food Science 30: 178-182.

Sinensky M (1974). Homeoviscous adaptation-Homeostatic process that regulates viscosity of membrane lipids in Escherichia coli. Proceedings of the National Academy of Sciences of the United States of America 71: 522-525.

Singh A, Ward OP (1997). Microbial production of docosahexaenoic acid (DHA, C22: 6). Advances in Applied Microbiology 45: 271-312.

Siron R, Giusti G, Berland B (1989). Changes in the fatty acid composition of Phaeodactylum tricornutum and Dunaliella tertiolecta during growth and under phosphorus deficiency. Marine Ecology Progress Series 55: 95-100.

Springer M, Franke H, Pulz O (1994). Increase of the content of polyunsaturated fatty acids in Porphyridium cruentum by low-temperature stress and acetate supply. Journal of plant physiology 143: 534-537.

Steele NM, Fry SC (2000). Differences in catalytic properties between native isoenzymes of xyloglucanendotransglycosylase (XET). Phytochemistry 54: 667-680.

Stillwell W, Wassall SR (2003). Docosahexaenoic acid: Membrane properties of a unique fatty acid. Chemistry and Physics of Lipids 126: 1-27.

Stinson EE, Kwoczak R, Kurantz MJ (1991). Effect of cultural conditions on production of eicosapentaenoic acid by Pythium irregulare. Journal of Industrial Microbiology 8: 171-178.
Strasser RJ, Srivastava A, Tsimilli-Michael M (2000). The fluorescence transient as a tool to characterise and screen photosynthetic samples. In: Yunus M, Pathre U, Mohanty P (eds.), Probing Photosynthesis: Mechanism, Regulation and Adaptation, pp. 443-480. London: Taylor \& Francis.

Sukenik A (1991). Ecophysiological considerations in the optimization of eicosapentaenoic acid production by Nannochloropsis sp. (Eustigmatophyceae). Bioresource Technology 35: 263-269.

Sukenik A, Zamora O, Carmeli Y (1993). Biochemical quality of marine unicellular algae with emphasis on lipid composition. II. Nannochloropsis sp. Aquaculture 117: 313-326.

Sushchik NN, Kalacheva GS, Zhila NO, Gladyshev MI, Volova TG (2003). A temperature dependence of the intra- and extracellular fatty-acid composition of green algae and cyanobacterium. Russian Journal of Plant Physiology (English Translation) 50: 374-380.

Tassoni D, Kaur G, Weisinger RS, Sinclair AJ (2008). The role of eicosanoids in the brain. Asia Pacific Journal of Clinical Nutrition 17: 220-228.

Teoh ML, Chu WL, Marchant H, Phang SM (2004). Influence of culture temperature on the growth, biochemical composition and fatty acid profiles of six Antarctic microalgae. Journal of Applied Phycology 16: 421-430. DOI 10.1007/s10811-004-5502-3.

Teoh ML, Phang SM, Chu WL (2013). Response of Antarctic, temperate, and tropical microalgae to temperature stress. Journal of Applied Phycology 25: 285-297. DOI 10.1007/ s10811-012-9863-8.

Thompson PA, Guo MX, Harrison PJ, Whyte JNC (1992). Effects of variation in temperature on the fatty-acid composition of 8 species of marine-phytoplankton. Journal of Phycology 28: 488-497. DOI 10.1111/j.0022-3646.1992.00488.x.

Thyssen M, Ferreyra G, Moreau S, Schloss I, Denis M, Demers S (2011). The combined effect of ultraviolet $B$ radiation and temperature increase on phytoplankton dynamics and cell cycle using pulse shape recording flow cytometry. Journal of Experimental Marine Biology and Ecology 406: 95-107. DOI 10.1016/j.jembe.2011.06.015.

Tonon T, Harvey D, Larson TR, Graham IA (2002). Long chain polyunsaturated fatty acid production and partitioning to triacylglycerols in four microalgae. Phytochemistry 61: 1524. DOI 10.1016/S0031-9422(02)00201-7.

Torstensson A, Jiménez C, Nilsson AK, Wulff A (2019). Elevated temperature and decreased salinity both affect the biochemical composition of the Antarctic sea-ice diatom Nitzschia lecointei, but not increased $\mathrm{pCO}_{2}$. Polar Biology 42: 2149-2164.

Twining C, Bernhardt J, Derry A, Hudson CM, Ishikawa A et al. (2021). The evolutionary ecology of fatty-acid variation: Implications for consumer adaptation and diversification. Ecology Letters 24: 1-23. DOI 10.1111/ele.13771.

Twining CW, Brenna JT, Hairston NG, Flecker AS (2015). Highly unsaturated fatty acids in nature: What we know and what we need to learn. Oikos 125: 749-760.

Uauy R, Mena P, Rojas C (2000). Essential fatty acids in early life: Structural and functional role. Proceedings of the Nutrition Society 59: 3-15.

Vaezi R, Napier JA, Sayanova O (2013). Identification and functional characterization of genes encoding Omega-3 polyunsaturated fatty acid biosynthetic activities from unicellular microalgae. Marine Drugs 11: 5116-5129.

Van Doorslaer W, Stocks R, Jeppesen E, de Meester L (2007). Adaptive microevolutionary responses to simulated global 
warming in Simocephalus vetulus: A mesocosm study. Global Change Biology 13: 878-886.

Varkey D, Mazard S, Ostrowski M, Tetu SG, Haynes P, Paulsen IT (2016). Effects of low temperature on tropical and temperate isolates of marine Synechococcus. ISME Journal 10: 1252-1263.

Vincent WF (2000). Cyanobacterial dominance in the polar regions. In: The Ecology of Cyanobacteria, pp. 321-340. Dordrecht: Springer.

Von Elert E (2004). Food quality constrains in Daphnia: Interspecific differences in the response to the absence of a long chain polyunsaturated fatty acid in the food source. Hydrobiologia 526: $187-196$

Wada H, Gombos Z, Murata N (1990). Enhancement of chilling tolerance of a cyanobacterium by genetic manipulation of fatty acid desaturation. Nature 347: 200-203.

Wada H, Murata N (1990). Temperature-induced changes in the fatty acids composition of the cyanobacterium, Synechocystis PCC 6803. Plant Physiology 92: 1062-1069.

Wen ZY, Chen F (2001). Application of statistically-based experimental designs for the optimization fo eicosapentaenoic acid production by the diatom Nitzschia leavis. Biotechnology and Bioengineering 75: 159-169.

Winder M, Sommer U (2012). Phytoplankton response to a changing climate. Hydrobiologia 698: 5-16.
Winter R, Dzwolak W (2005). Exploring the temperature pressure configurational landscape of biomolecules: From lipid membranes to proteins. Philosophical Transactions of the Royal Society of London Part A 363: 537-563.

Xu XQ, Beardall J (1997). Effect of salinity on fatty acid composition of a green microalga from an antarctic hypersaline lake. Phytochemistry 45: 655-658.

Yang YH, Du L, Hosokawa M, Miyashita K, Kokubun Y, Arai H, Taroda H (2017). Fatty acid and lipid class composition of the microalga Phaeodactylum tricornutum. Journal of Oleo Science 66: 363-368.

Zainal Abidin ZA, Zainuddin Z, Wan Mastrai SFQ, Mohd Sidik Merican FM, Convey P (2020). Fatty acid profiles of Antarctic cyanobacteria Leptolyngbya. Journal of Environmental Biology 41: 687-694.

Zhu CJ, Lee YK, Chao TM (1997). Effects of temperature and growth phase on lipid and biochemical composition of Ishochrysisgalbana TK1. Journal of Applied Phycology 9: 451-457. DOI 10.1023/ A:1007973319348.

Zulu NN, Zienkiewicz K, Vollheyde K, Feussner I (2018). Current trends to comprehend lipid metabolism in diatoms. Progress in Lipid Research 70: 1-16. DOI 10.1016/j. plipres.2018.03.001. 